\title{
Traces in the desert: use of new technologies for the study and valorization of the Pachacamac sanctuary-Lima, Peru
}

\author{
Denise Pozzi-Escot ${ }^{1 *}$, Janet Oshiro ${ }^{1}$, Gerardo Romano ${ }^{2}$, Luigi Capozzoli ${ }^{3}$, Rosa Lasaponara ${ }^{3}$ and Nicola Masini ${ }^{4^{*}}$
}

\begin{abstract}
Through time, the large ceremonial centers of the Peruvian pre-Hispanic coast have played an important role as Pachacamac, renowned for its famous oracle, which was an important site for cult and pilgrimage, where the use of water entered largely into ritual functions during Inca age and before. The sanctuary's landscape included sea, valley and lomas (ecosystem of grassy, seasonal knolls), and a complex and elaborate system of springs and canals which seem to use both the natural water table and the waters of the nearby Lurin river. In this sacred landscape there are over fifty buildings associated to springs and canals, built during a long occupation spanning over a 1000 years. This entire system must have been connected to Urpiwachaq lagoon, located to the northeast and only a few kilometers away from the sea. The origins of the lagoon and its relationship with the archaeological site evoke creation myths for the waters and marine species of the central coast. In this paper we discussed the results obtained from the geophysical investigations performed to define the water management system in the sanctuary and their connection with the lagoon. In particular, geo-electric, geomagnetic and ground penetrating radar prospections were carried out in the monumental area to determine the trajectory of the waters that drained into the lagoon from a series of ponds and canals. The interdisciplinary work in both the lagoon and monumental area provided a valuable source of information useful to better understand the history and function of the Pachacamac sanctuary in prehispanic times.
\end{abstract}

Keywords: Acllawasi, Canal, Geomagnetic, Geoelectrical, Urpiwachaq lagoon

\section{Introduction and research aims}

The archaeological sanctuary of Pachacamac was occupied and transformed by the Incas from 1470 AD until 1533 AD. During those years, a number of buildings including the Acllawasi or Mamacona were built.

The Incas built the Acllawasi for women dedicated to the cult of the Sun God, and for the production of fine goods for the temple complex. The building is composed of three sectors: large structures with galleries and staircases and large open patios. The trapezoidal niches within and around various rooms as well as the decorated ashlars and windows, are all characteristic of the typical Inca architecture. Within the complex, researchers found several ponds that probably had a ceremonial function.

\footnotetext{
*Correspondence: dpozzi@cultura.gob.pe; nicola.masini@cnr.it

${ }^{1}$ Pachacamac Museum-Ministry of Culture of Peru, Lima, Peru

${ }^{4}$ CNR-Istituto per i Beni Archeologici e Monumentali, Potenza, Italy

Full list of author information is available at the end of the article
}

Based on the available archaeological records emerged the hypothesis of the existence of a complex system of water which converged to Acllawasi ponds and flew through canals in the lagoon of Urpiwachaq [1].

The existence of ponds inside and outside the Acllawasi building, as well as some visible fragments of canals (for additional details see "System of canals in the sanctuary of Pachacamac") fostered the development of a project whose objective was to define the network of existing canals in the sanctuary.

With the aim to better define the canalization system and characterize the water table geophysical studies were carried out using three different techniques. This is a first step to improve the current knowledge oriented at supporting decisions and strategies addressed to cultural and natural heritage conservation and management. 


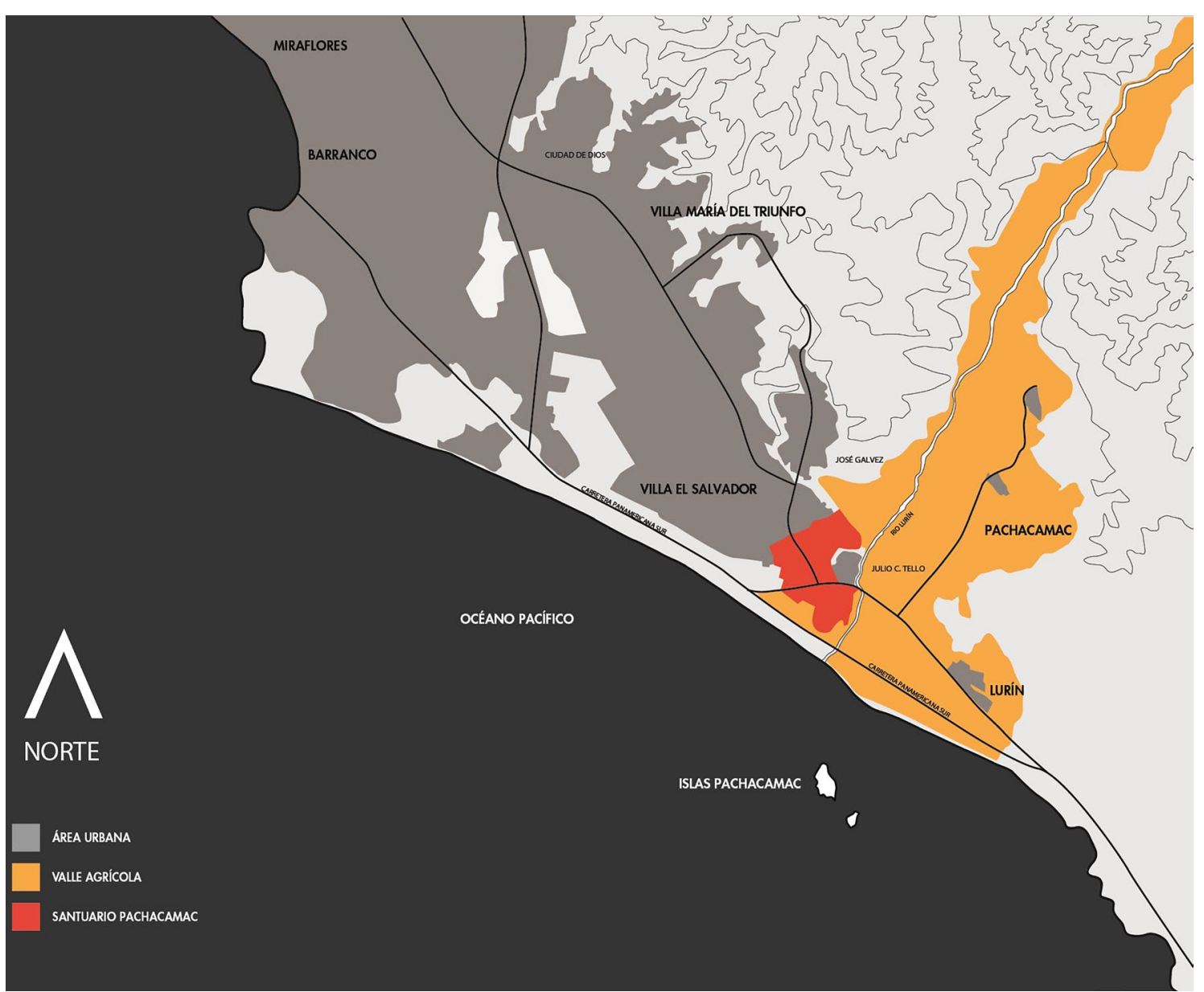

Fig. 1 Archaeological sanctuary of Pachacamac

\section{Study area}

\section{The sanctuary of Pachacamac}

The importance of the archaeological sanctuary of Pachacamac (Fig. 1) is based on the deity that housed, considered the most important for yungas (coastal) societies, because it was related to earthquakes, and a "single movement of his head made the earth tremble" [2]. For this reason, Pachacamac was one of the most powerful oracles of the Andes: pilgrims arrived during the Inca occupation through the main Inca road or Qhapaq Nan.

The sanctuary was the scene of development of different cultures, which is reflected in the architecture and materials such as pottery, textiles, and metals, among others.

During the Early Intermediate Period (Lima Culture 200 AD-600 AD), the first temples as the Old Temple and the Adobes Lima Complex or "Adobitos" were built in the sanctuary. These were made using small adobes placed in bookcase form. Then, during the Middle
Horizon (600 AD-1100 AD), there is a strong Wari influence in the central coast, which is reflected in the pottery and fine textiles, as well as funerary contexts [3, 4].

During the Late Intermediate Period, the valleys of Rimac and Lurin rivers were occupied by the Ychmas (1100 AD-1470 AD). They built a series of pyramids with ramps, made in stones carved at the foundations and walls in adobe bricks, whose functions are still subject of discussion among specialists.

With the Ychmas, the power and fame of Pachacamac spreed along the central coast. With the arrival of the Incas, during the Late Horizon (1470 AD-1533 AD), the ancient Lima temples were reoccupied. The urban space of Pachacamac was rearranged with the construction of the temple of the Sun, the Acllawasi, the Pilgrims Square and the temple of Pachacamac, among others. The North-South street (the main pilgrimage route in the sanctuary connected to the Inca road; see Fig. 2) was reordered and other buildings were constructed, such as Taurichumpi and the "House of the 


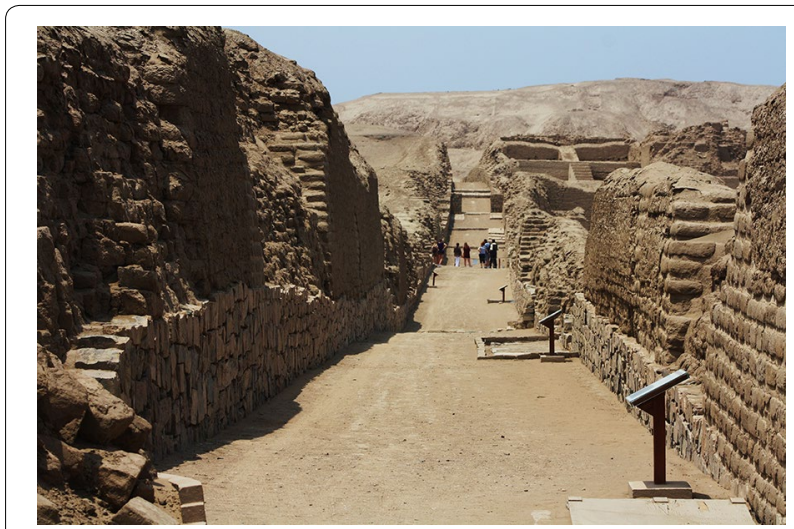

Fig. 2 Detail of Pachacamac: North-South Street (for its location in map see Fig. 3)

Quipus", local administrative buildings serving the Inca Empire. At this time, the oracle acquired great importance, becoming one of the main oracles of the Andean region, receiving a large number of pilgrims who came from faraway places.

Since 2008, Pachacamac Museum has been developing archaeological research programs, complemented with the conservation of the monumental area of the sanctuary, extensions of the touristic circuit, and educational programs.

\section{Urpiwachaq lagoon}

The Urpiwachaq lagoon is a natural formation that is the result of the separation of a large lagoon ending in small wetlands [5]. Some researchers have pointed out the benefits offered by the lagoon and the Lurin River for the formation and growth of the Pachacamac complex [6]. Apparently, the first settlers had to take advantage of the resources of the lagoon [7], which favored the settlement in its proximity.

According to the myths related to Pachacamac, as reported in Huarochiri Manuscript [8], Urpay Wachaq was considered wife of Pachacamac. She was the marine species and fish goddess, who allowed that fish populated the oceans by throwing a vase full of fish into the sea, in front of the sanctuary of Pachacamac. In addition, we must consider that probably the myth was transmitted by the fishermen to mountain populations along the valleys of the Lurin and Lima rivers. In the mountain areas five sisters of Pariaqaqa (one of the most important deities of Tawantinsuyo) were worshiped. One of them was Urpay Wachaq or Urpiwachaq [9].

Towards the end of the Late Intermediate period (1100 $\mathrm{AD}-1470 \mathrm{AD}$ ) and the beginning of the Inca occupation, a set of perimeter stone and adobe walls, with access and steps, were built around the lagoon, restricting the access to this space. They also built a set of ponds and stone canals that associated the lagoon with the Acllawasi.

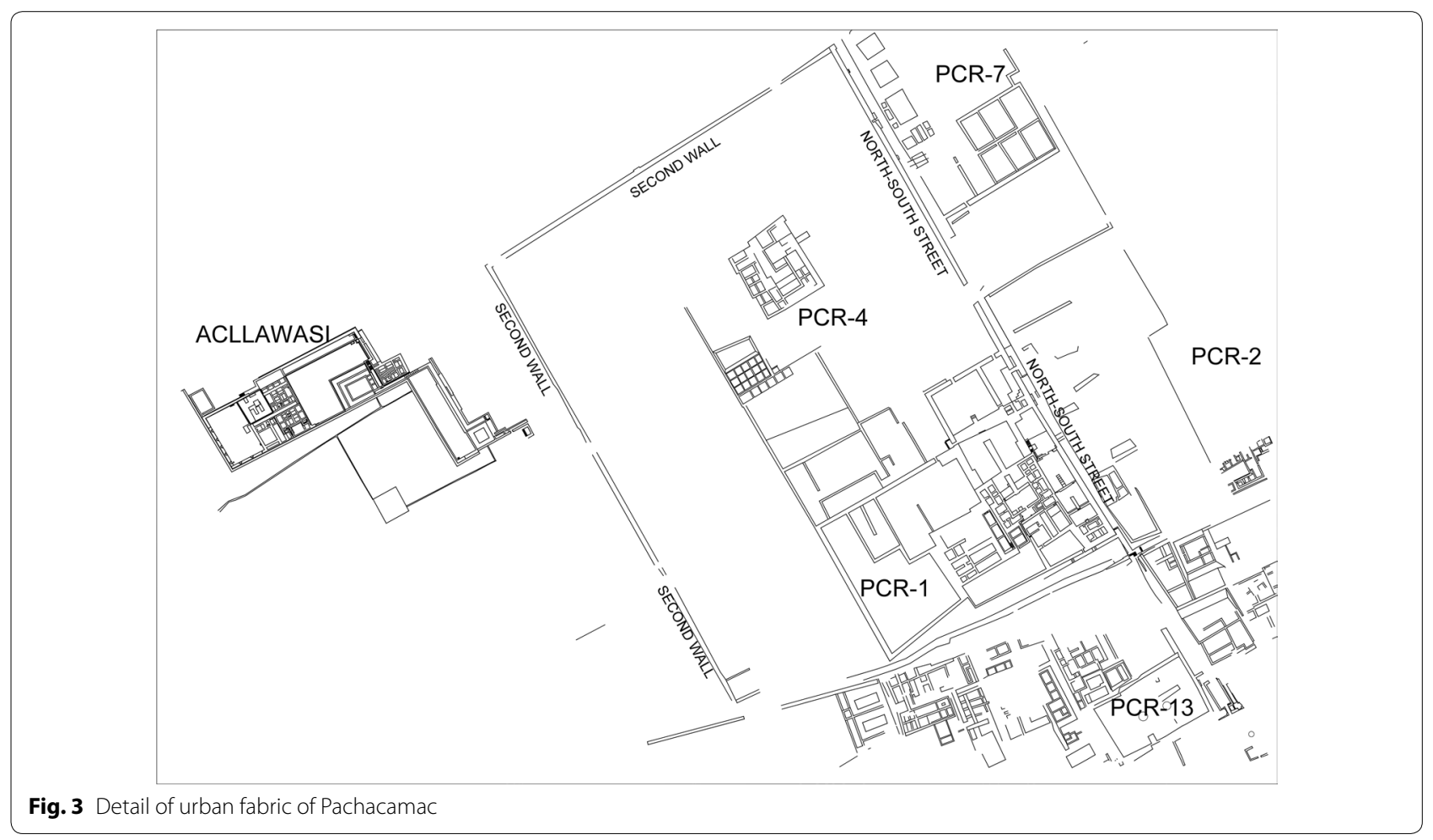


Apparently, at Inca times the waters of the Acllawasi (Fig. 3) ponds flowed into the lagoon through these canals (Fig. 4).

\section{Archaeological and geological investigations}

From Max Uhle, at the beginning of the last century [10], researchers were interested in the area, recording the dimensions and characteristics of the lagoon. In 1941, Tello observed that the lagoon had a large volume of water and was populated by totorales and a considerable amount of ducks [11]; that is why he called it "Lagoon of ducks".

Archaeological investigations conducted in the proximity of the lagoon $[6,11-17]$ permitted to identify the following archaeological remains:

- The northern perimeter wall bordering the sandy block that extends to the north of the lagoon, marking an effective limit between the desert area and the cultivated lands that extend to the south of this area.

- A rectangular building approximately $92 \mathrm{~m}$ long and $64 \mathrm{~m}$ wide, located on the plain surrounding the lagoon, northwest of it.

- The western perimeter wall made up of a row of rooms aligned along two parallel walls at a distance of $2.60 \mathrm{~m}$, which can reach more than $250 \mathrm{~m}$ in length. This row of rooms, which has the shape of an alley, probably in ancient times, marked the western boundary of the lagoon area. This wall spliced at right angles to the missing perimeter wall south of the lagoon.

In 2011, in collaboration with the Pacifico University, the research and valorization project of the Urpiwachaq lagoon was developed in order to recover the landscape values of the lagoon, mitigate the negative impacts, and design new tourist routes. The excavation permitted the recovery of the typical malacological remains (such as Helisoma trivolvis, Depanotrema vimayanun, Physa Peruviana, Heleobia cumingli and Physa venustula.) as well as of machas (Mesodesma donacium) and 68 diagnostic fragments of pottery that associate it with Ychma and Inca styles of the Late Horizon (1470 AD-1533 AD).

The studies we conducted in four cuts of up to $1.88 \mathrm{~m}$ deep in the Urpiwachaq lagoon allowed us to understand the process of its formation and the natural events that happened until present. The sediments analysis (the sands with remnants of disordered clasts, fragments of gastropods and bivalves, rocks, ripples of current) along

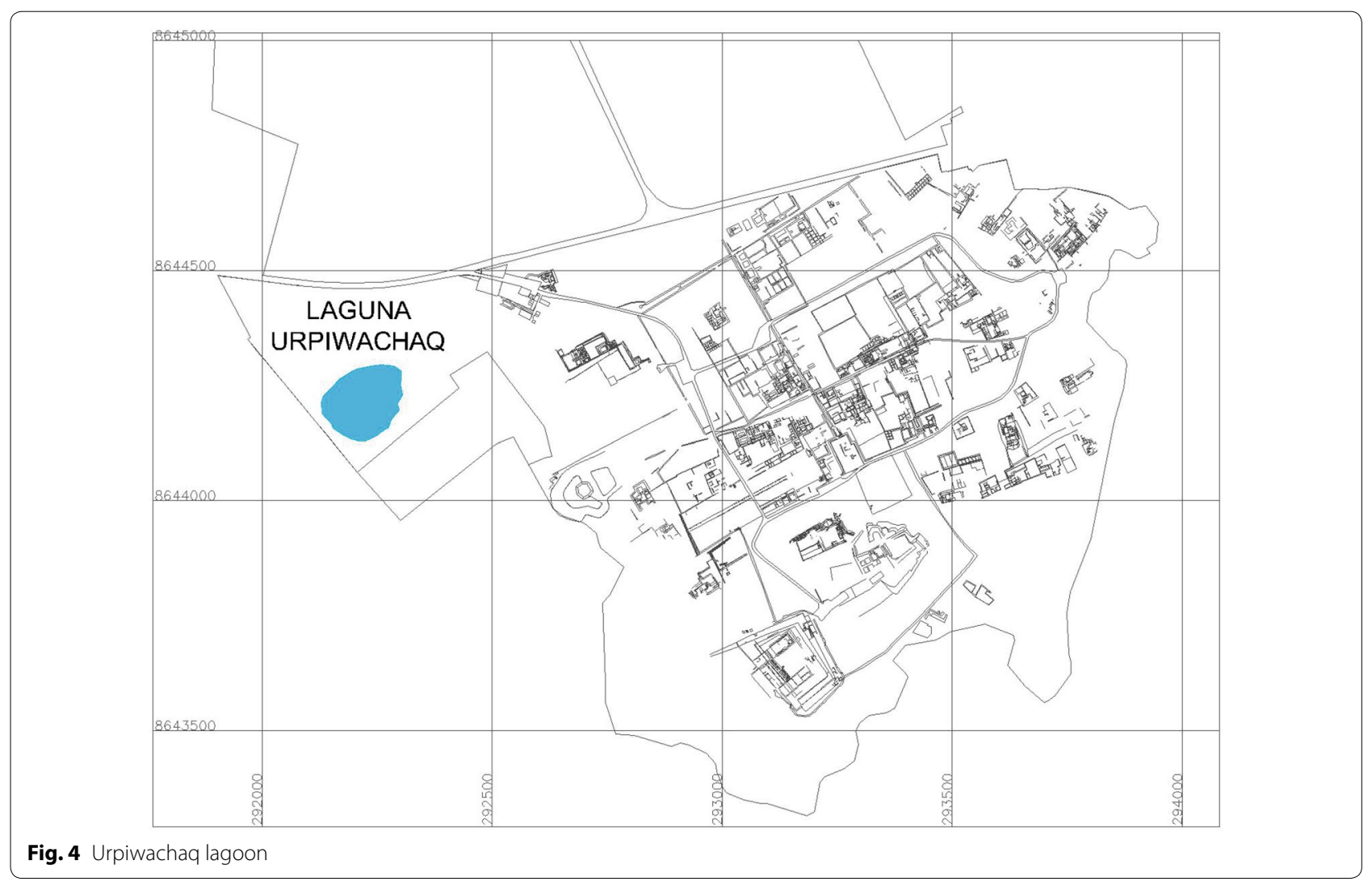


with the erosive character of these levels of sand present in the cuts evidenced a possible tsunami event (Fig. 5).

\section{System of canals in the sanctuary of Pachacamac}

The archaeological investigations with excavations in the sanctuary of Pachacamac allowed us to record a series of prehispanic canals constructed with flat stones of quadrangular shape and arranged to form smooth surfaces that diminish the filtrations (see Figs. 6, 7 and 8).

Max Uhle was the first to mention the ponds located in the building of "Las Mamaconas" or Acllawasi $[10,18]$. The first specific study is due to Tello [11] who investigated the pond system in relation to the architectural context-which he called Temple of the Moon-and the characteristics of the groundwater table. In this sense, Tello observed that water "emerged from the subsoil in the manner of spouts, drained by a conduit to the canal that feeds the Urpay Huachac lagoon" [18]. In addition, he discovered ponds of different sizes, whose sidewalls were and still are today covered with stones, and canals that served to capture the water and take it to the pools near the lagoon. The network of ponds and canals allowed the management of water for domestic use, raising ducks and irrigation according Tello [11].

Herman Buse said that the relationship between the hydraulic system of pools and canals with a building of surprising architectural design includes a great planning and excellent management of the space. A document of

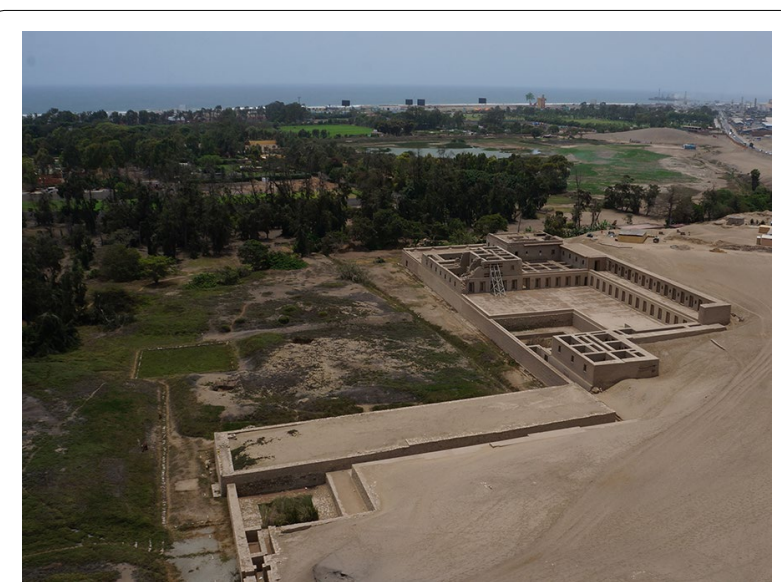

Fig. 6 Acllawasi and Urpiwachaq connected by ponds and canals

1568 found in the Archivo General de Indias of Seville [18] mentions "[..] a lagoon or pond of salt water next to the sea and the port [..]" where "[..] a certain genus of fish that is taken in the sea... grows and fattens". What is stated in the document seems to be confirmed by the chronicler Francisco de Avila who offers a legendary and mythological version of the site that deserves a deepening in the context of analysis of pacarinas or myths of origin. However, the chronicler mentions a function of the lagoon as fish hatchery for the Acllawasi diet.

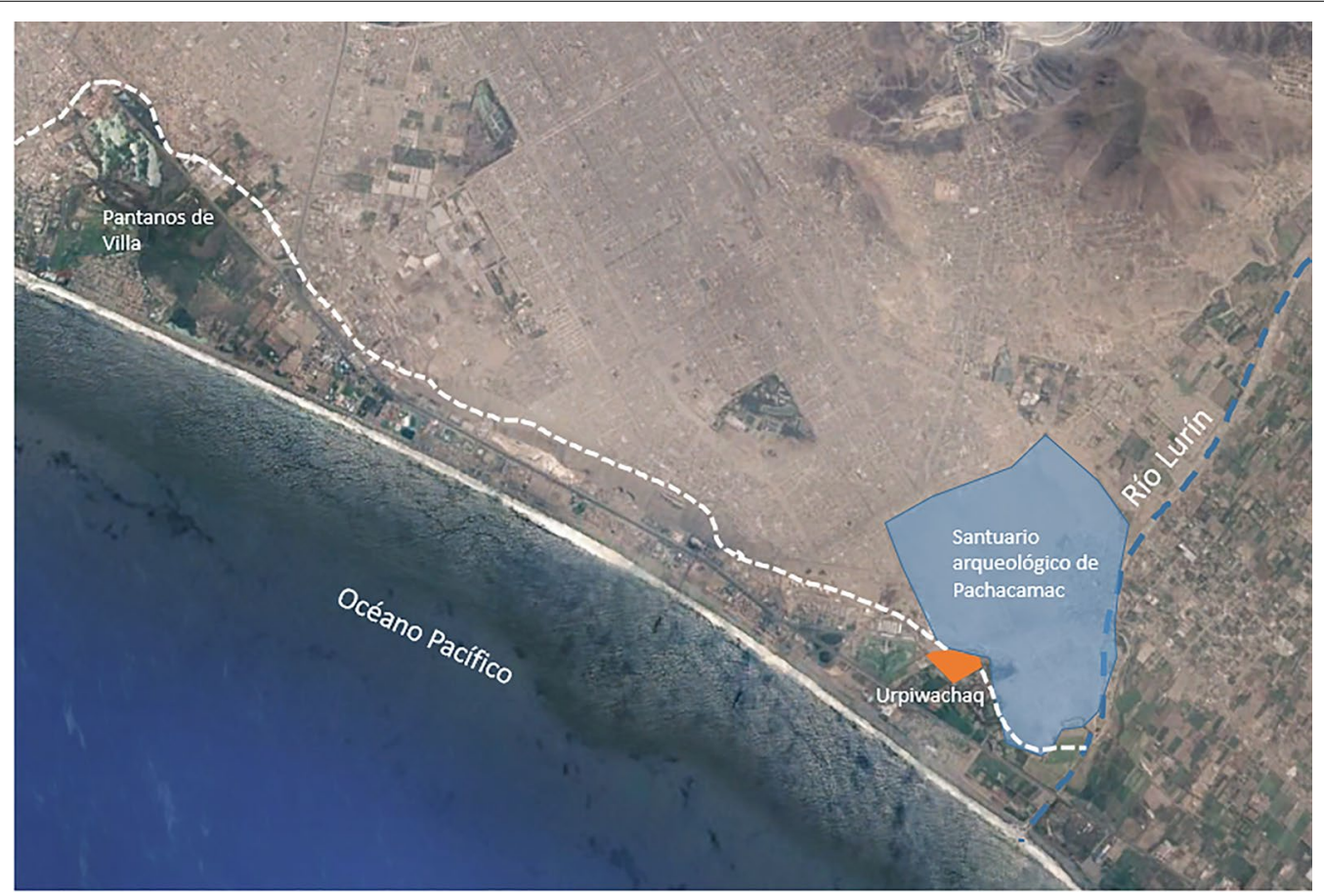

Fig. 5 Urpiwachaq location 


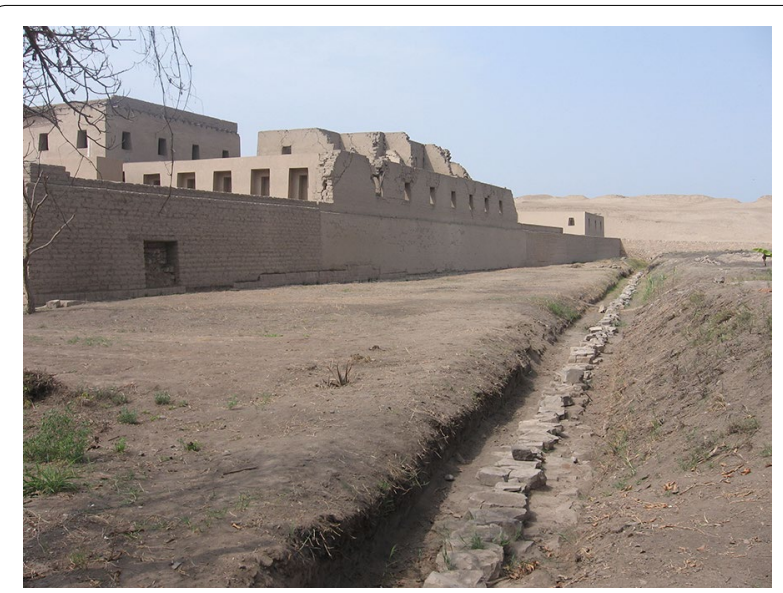

Fig. 7 Acllawasi stone canal

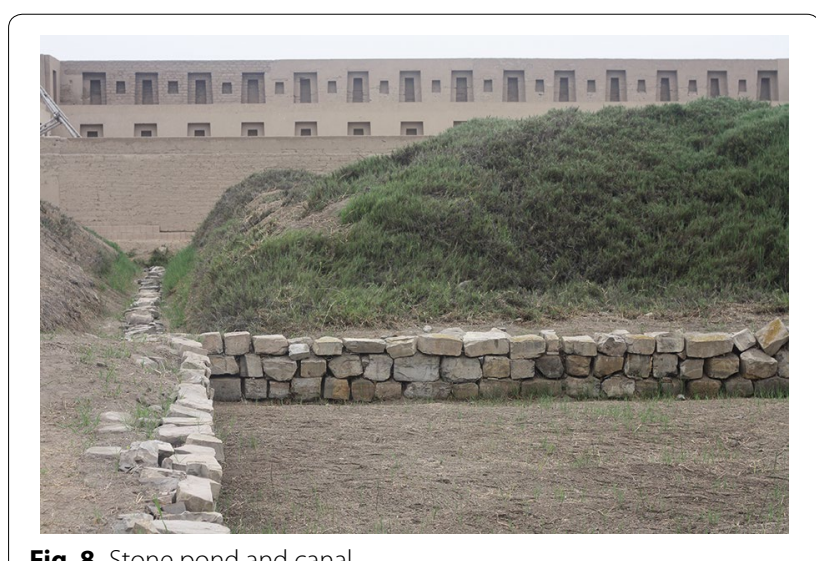

Fig. 8 Stone pond and canal

In the framework of the Archaeological Research project of North-South street and the Second Wall and a project of Italian Mission of the CNR (2013 CNR Report), archaeo-geophysical investigations were conducted to improve the knowledge the water management system, starting from some excavation trials unearthed some sections of canals. The first is parallel to the north of the Second Wall (see Fig. 9) in an EastWest direction that probably led to the Acllawasi. A second section is inside the North-South Street (parallel to the West Wall). A third section, crossing the North-South Street, conveyed the water west towards the Acllawasi [19, 20]. Finally, another canal was recorded in the current Casuarinas forest (see Fig. 10). At the height of the Acllawasi $[15,17]$, this would be the projection of a canal discovered and recorded by Tello in 1941, which served to drain the Acllawasi's pond. It consists of two parallel rows of semi-edged stones, covered by a slab in the manner of a false vault, according to the projection of this canal, it is considered that the

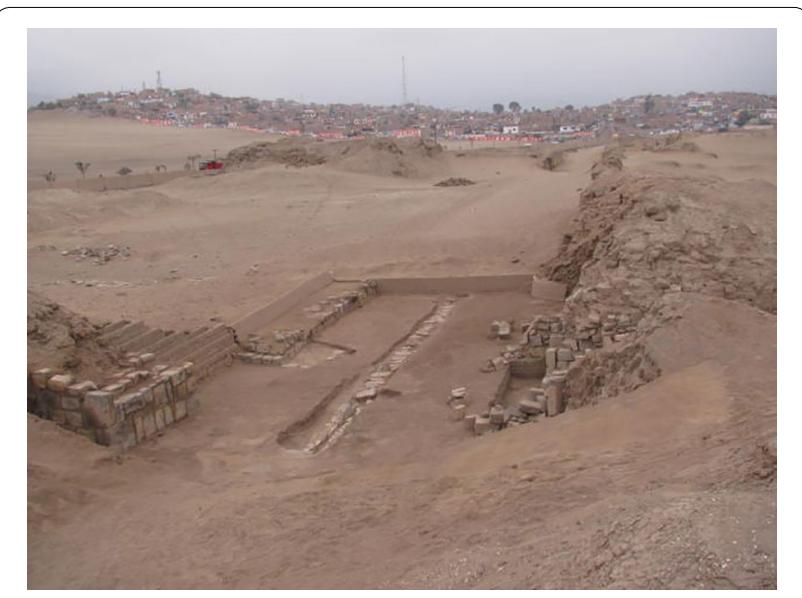

Fig. 9 Canal near the second wall

waters that ran through it ended up feeding the Urpiwachaq lagoon.

\section{Archaeogeophysical approach used for the study of the Urpiwachaq lagoon}

Since 2012, the research team of Pachacamac Museum and ITACA mission of CNR [21] have conducted studies in the Sanctuary of Pachacamac, with the objective to define and map the water canal system.

Based on the results of trial excavations which unearthed a number of canal sections (see paragraph "System of canals in the sanctuary of Pachacamac"), and other ancillary data, emerged the need to deepen the knowledge of canal system in particular reference in the area between Acllawasi and the lagoon of Urpiwachaq (see Fig. 11).

To this aim geophysical studies were performed using and integrating different methods, including the geomagnetic method, ground penetrating radar (GPR), and electrical resistivity tomography (ERT).

These methods offer several advantages in the field of preventive archaeological research [22]. In particular, they are non-invasive and reduce time and costs necessary for the study and research. Their integration enables us to overcome the intrinsic limitation of a single geophysical method, facilitating the archaeological interpretation of prospections. The results of a single geophysical prospection have been carefully georeferenced and overlapped over satellite imagery and orthophoto derived from drone survey.

Figure 12 shows the entire integrated approach including geophysical prospections and ancillary data. The latter have been fruitfully used for both the planning of geophysical survey and the interpretation of their results. 


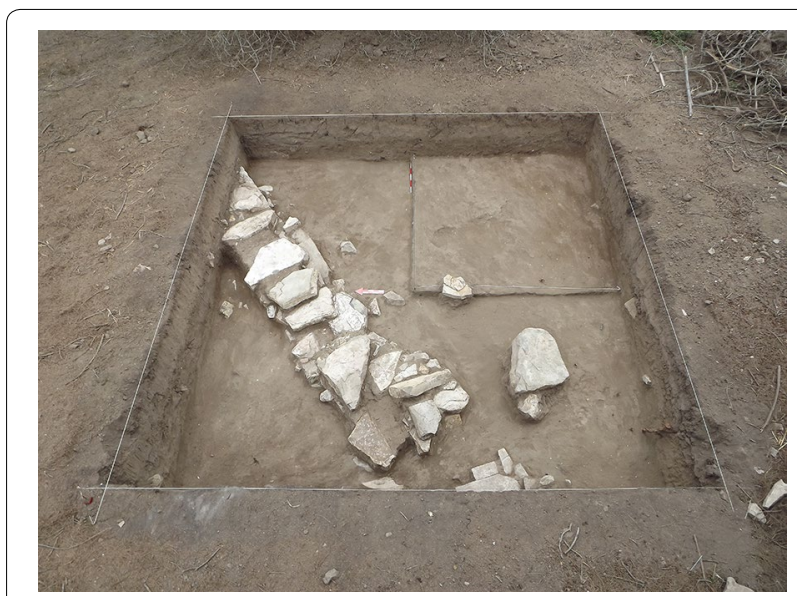

Fig. 10 Casuarinas forest canal

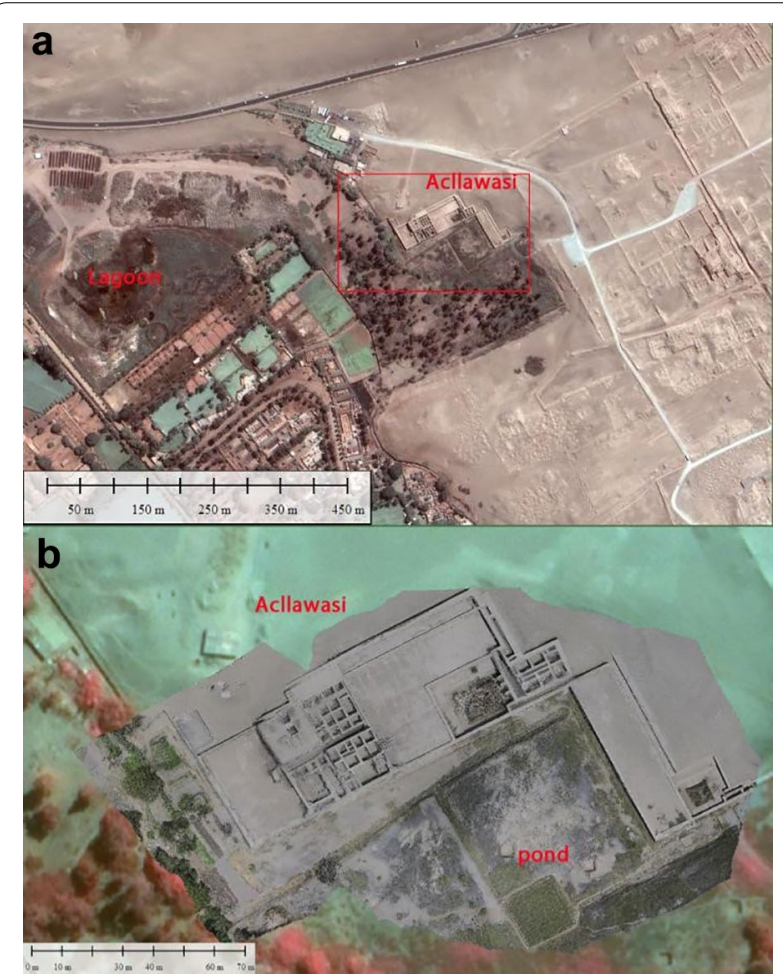

Fig. 11 a True color satellite orthophoto of the study area including the lagoon and the Acllawasi. Red box indicates the zoom showed in b. $\mathbf{b}$ Orthophoto obtained by drone survey of Acllawasi

The three geophysical methods (for additional details see following three paragraphs) have been selected to characterize both shallow and deep layers in order to image the presence of drainage and adduction canals close to the ponds and the lagoon (in particular using Magnetic and GPR methods) and the soil characterization up to an approximate depth of $50 \mathrm{~m}$ to identify potential aquifers (by ERT).

\section{GPR method}

GPR method is based on the emission and propagation of electromagnetic waves in a medium also including subsoil conserving buried archaeological remains. The subsequent reflection signals that occur in the discontinuities enable the physical characterizations of the material through which they propagate (electrical conductivity, magnetic permeability).

The reflected energy is detected by a receiving antenna operating at certain frequency that is tuned with the transmitted signal: lower is the frequency deeper is the penetration capability and lower is the resolution of the radar signals.

The buried structures reflect energy towards the surface and the remaining one continues to penetrate into greater depths. Georadar measurements are generally taken in different positions along defined lines and the corresponding radargrams are obtained. The correct interpretation of the radargrams allows us to obtain the depth of the object (target) where the reflection took place and also allows the morphological reconstruction of the imaged features and of the investigated medium.

The presence of clay soils with a high water content, as in the case of the Acllawasi study area, represents a limitation in terms of both penetration capability and resolution capacity. The combination of GPR technique with other methods, such as magnetic and geoelectrical analysis, can overcome these drawbacks. In the Acllawasi palace, as well as in other areas of Pachacamac [21], the investigations were carried out using a Georadar [22] equipped with low frequency antennas $(200-600 \mathrm{MHz})$ which for the current case study allowed us to image up to $1.50 \mathrm{~m}$ depth with a sufficient resolution suitable to detect structures and buried canals.

\section{Electrical resistivity tomography}

The electrical resistivity tomography (ERT) is a non-invasive geophysical technique for imaging the distribution of electrical properties (bulk resistivity) within the subsoil. It consists in injecting a direct current between the pair of electrodes fixed on the ground and measuring the voltage between the pair of the other electrodes that are also in contact with the ground. If the size and position of the measurement electrodes varies, the depth and the resolution of the investigation vary accordingly, allowing the definition of the geological characteristics, the detection of underground aquifers, and the identification of discontinuities related to archaeological structures [23].

The geoelectrical prospecting was carried out with different geometrical arrangement of the current and 


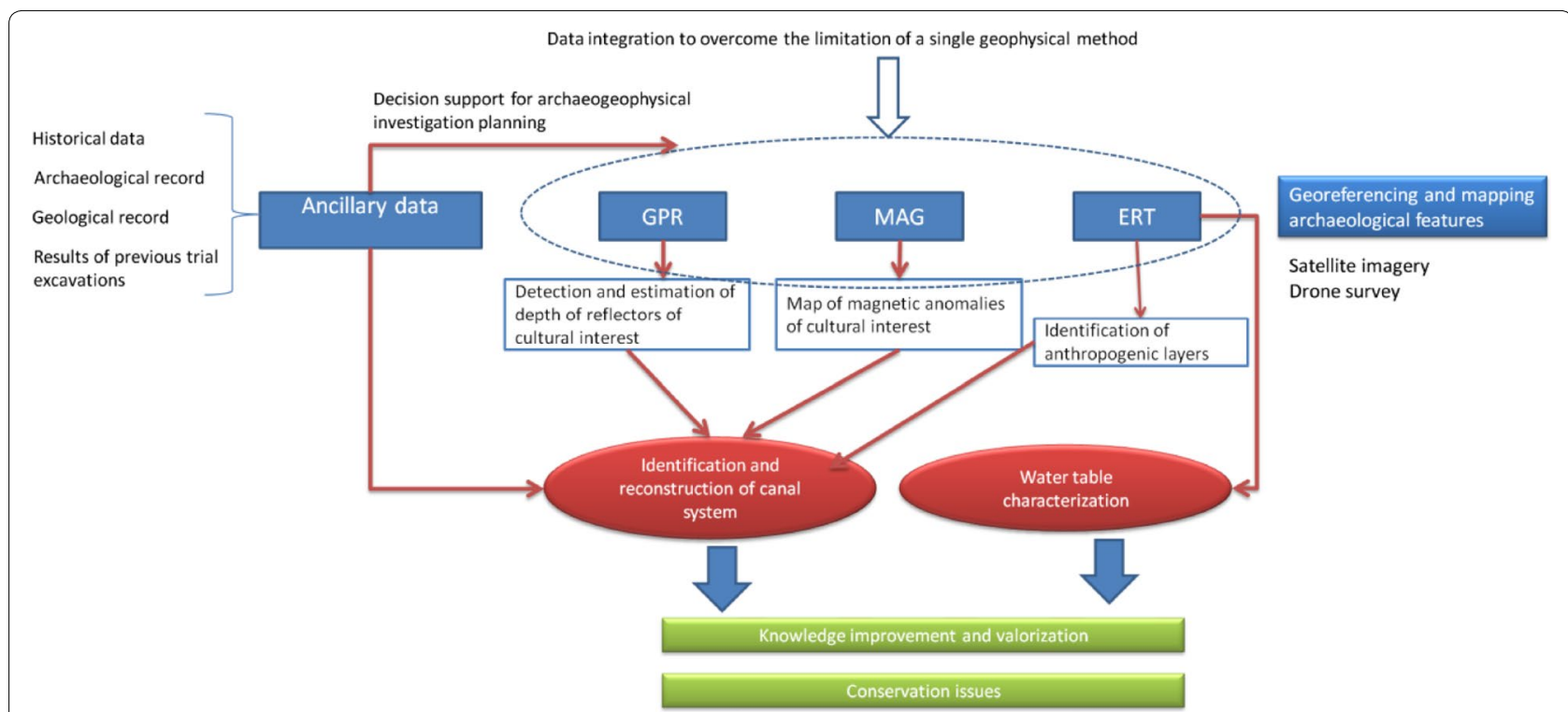

Fig. 12 Methodological approach based on the integration of different geophysical prospections and ancillary data, including archaeological, historical and geological record

potential electrodes in the terrain. The arrangement used was the Wenner configuration, in which the space between the potential and current electrodes increases constantly in the same proportion. This enables us to reduce the electrical noise induced naturally by the environmental factors of the terrain.

The acquired data were processed to obtain apparent resistivity values in pseudo-sections. At the end of the first stage of the data processing, these were converted into a suitable format to obtain 2D electric models.

The principle of this inversion program is based on the possibility of automatically creating a $2 \mathrm{D}$ model of resistivity for the subsoil, based on data measured on the surface by means of different combinations of geoelectric electrodes. The optimization method changes the model of the real resistivity, and repeatedly reduces the difference between the measured apparent resistivity and the values calculated by the model.

\section{Geomagnetic method}

Magnetic investigations are based on the hypothesis that the variations of the measured magnetic parameters are due to the variations of some properties of the subsoil [24]. The magnetic system is a versatile and portable instrument that allows a rapid measurement of the intensity of the earth's magnetic field. The measurements are generally made along parallel profiles, with a spacing and sampling step chosen each time according to the required details. Successively, they are elaborated by means of an adequate software and restored in maps where the individualized magnetic anomalies are represented by isolines or bands of color.

The instrument used for the geomagnetic measurements is the cesium vapor magnetometer G-858 from Geometrics. It consists of two sensors connected to a stirrup of diamagnetic material. During the measurement campaign, the magnetometer was always used with a gradiometric configuration, and the two sensors arranged at the vertices of a vertical stirrup, at a distance of approximately $0.8 \mathrm{~m}$ from each other.

All the geophysical maps have been overlaid on an orthophoto and digital elevation model obtained processing photos taken from a drone and using a photogrammetrical algorithm based on structure from motion implemented in software. It is based on a semi-automatic work-flow that manages the entire work phase, made up of: (i) orientation of the photos, (ii) generation of a point 

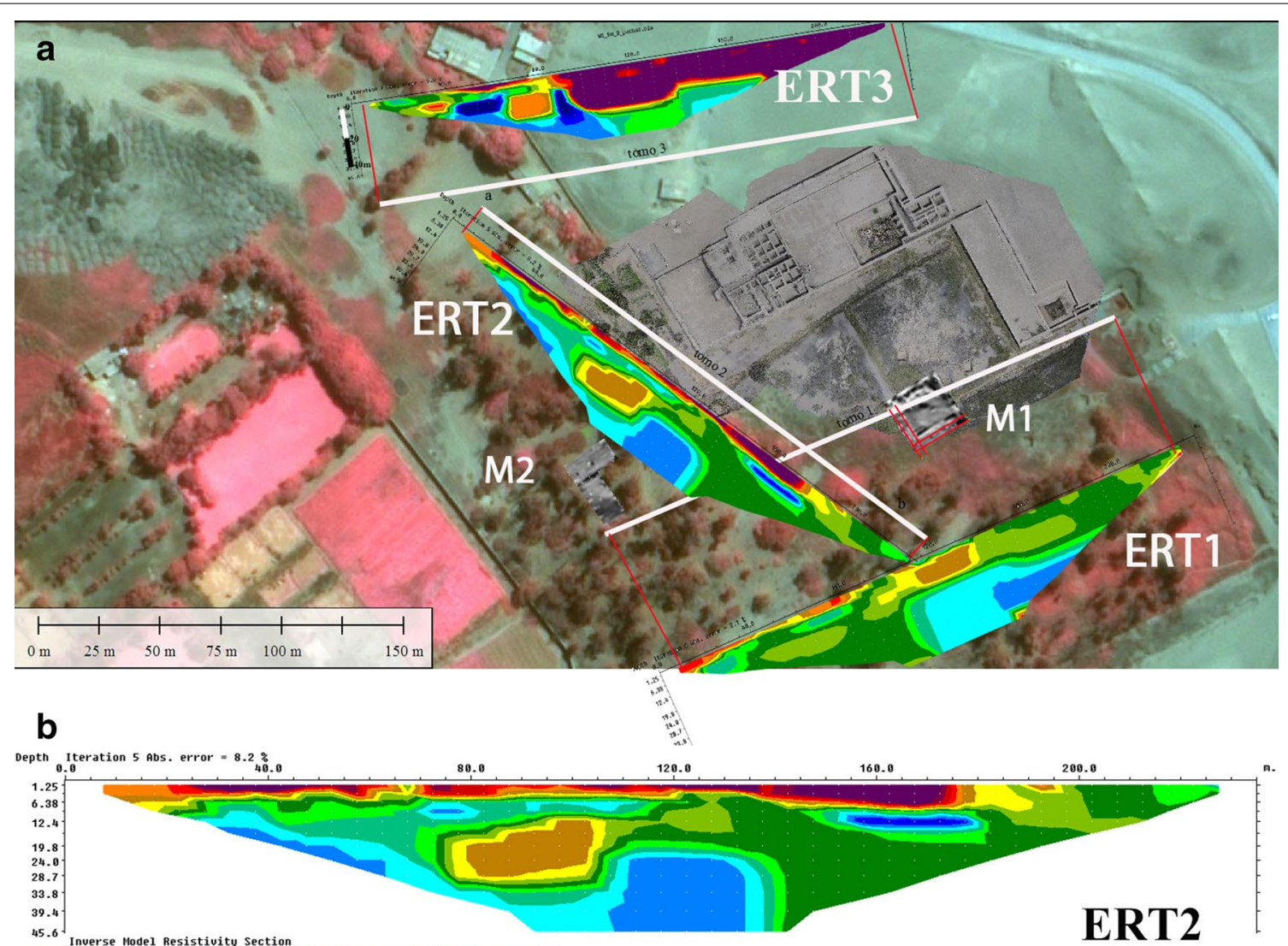

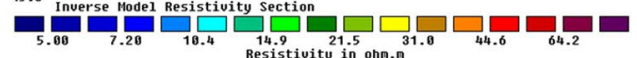

Unit electrode spacing $5.00 \mathrm{~m}$
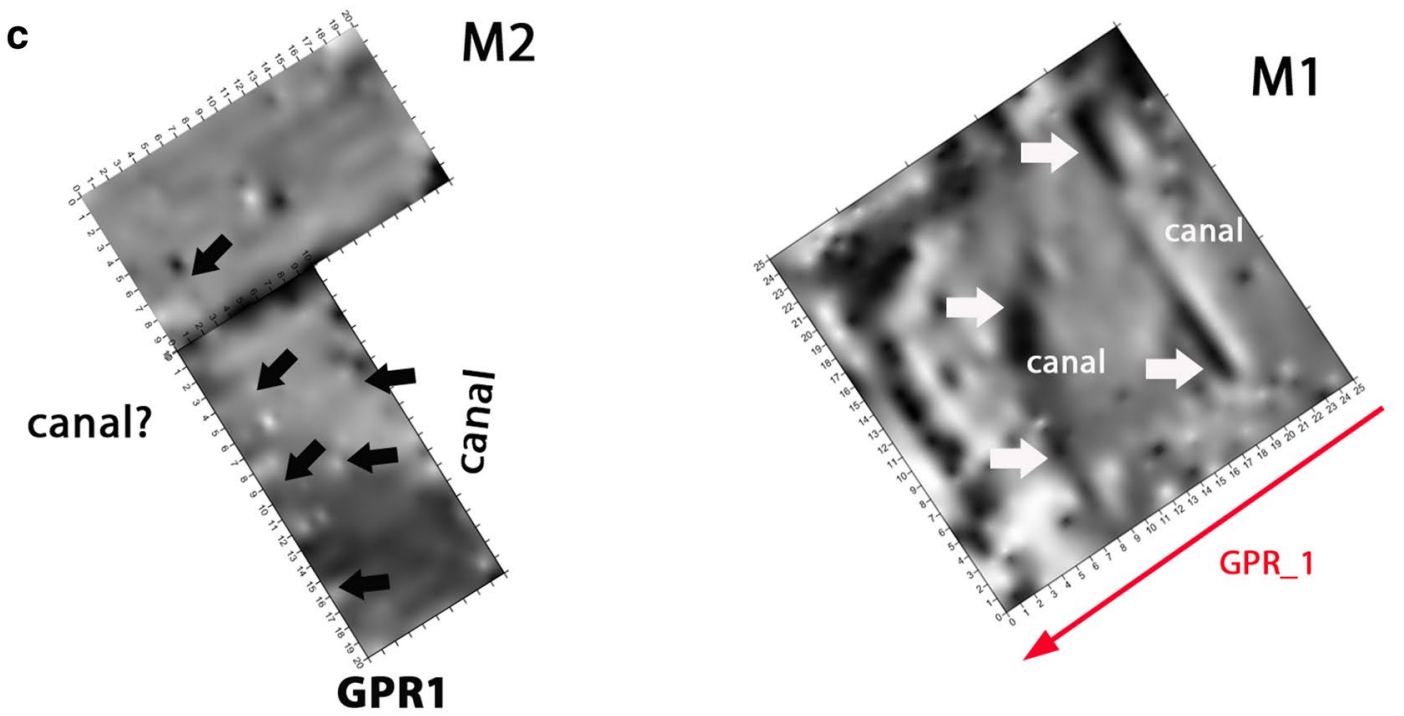

d

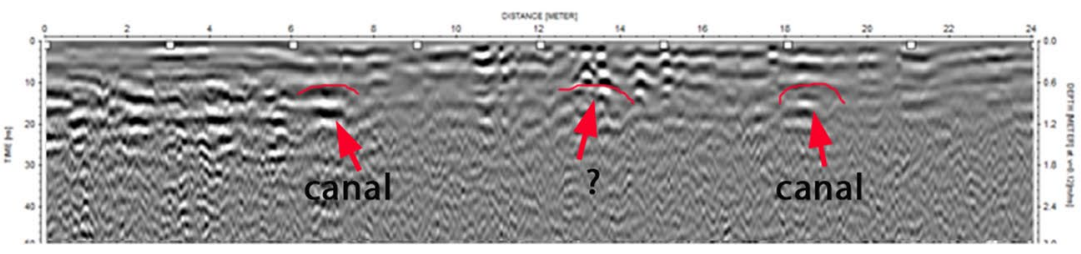




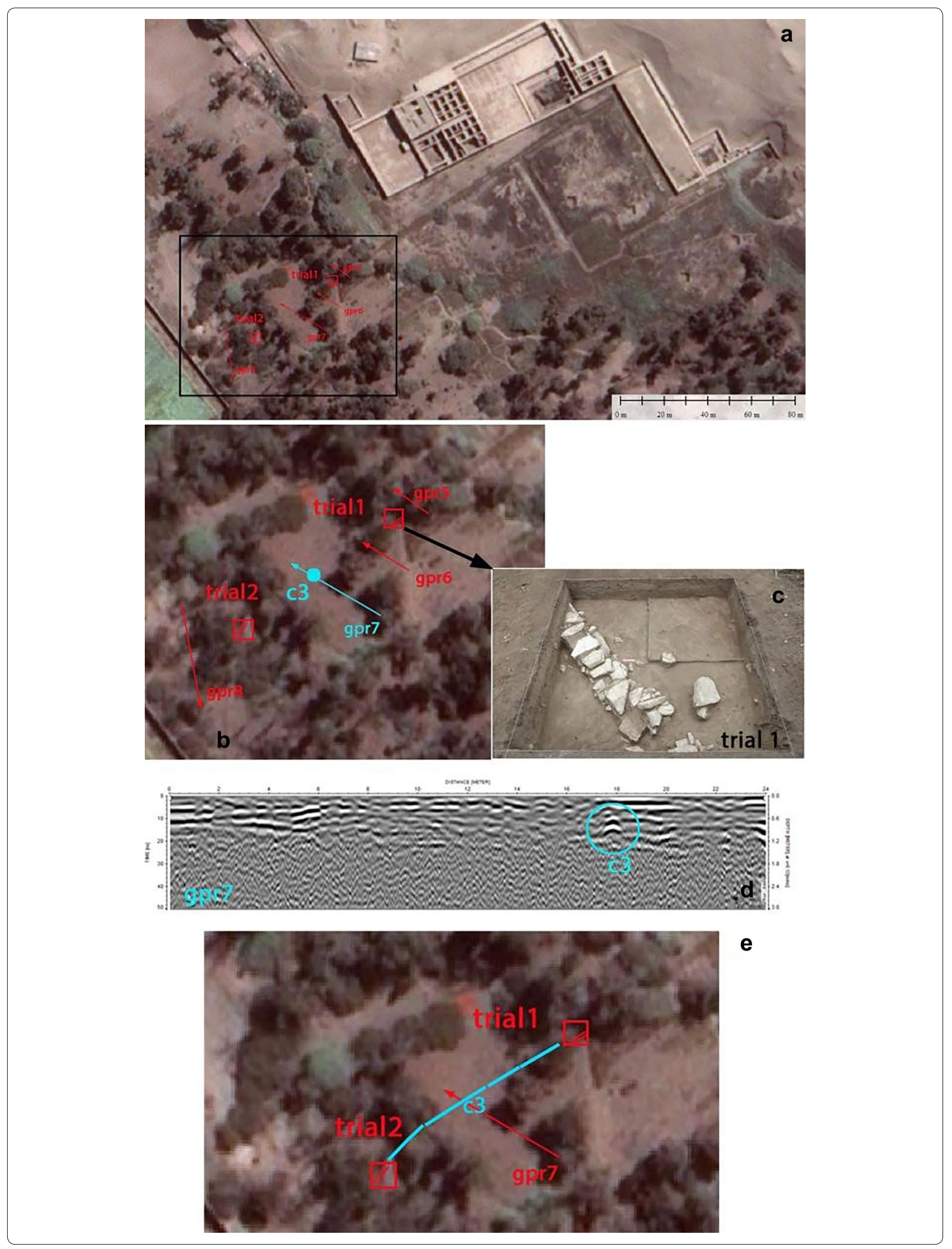


(See figure on previous page.)

Fig. 14 a Area investigated by GPR method located at South west of Acllawasi. b Zoom of the area indicated in $\mathbf{a}$ with the black box: the arrows indicate the GPR profiles, the red box indicate excavations trials 1 and 2 which reveal some section of a canal; $\mathbf{c}$ photo of excavation trial 1; d radargram gpr7 which evidences the presence of a reflector (c3) referable to the presence of a canal; e hypothesis of the canal path (cyan colored)

cloud, (iii) creation of a mesh and finally, (iv) 3D model covered by a very high resolution texture.

\section{Results and discussion}

Three geoelectrical measurements have been made in the Acllawasi surrounding, to the North, South and West, with direction respectively East-West (ERT3), Southwest-Northeast (ERT1) and Southeast-Northwest (ERT2) (see Fig. 13). The electrical resistivity tomographies were obtained with a length of $235 \mathrm{~m}$ and a maximum exploration depth of approximately $45 \mathrm{~m}$. The geo-electrical measurements were acquired using a multi-electrode system (Syscal Junior) at 48 canals with Wenner-Schlumberger configuration. The tomographies were processed using an inversion method based on the least squares procedure by a Gauss-Newton optimization technique [25].

ERT1 tomography puts in evidence two electro-layers (see Fig. 13). A superficial one until approximately $19 \mathrm{~m}$, that represents a heterogeneous area with the presence of resistive bodies ( $>50 \Omega * \mathrm{~m}$ ) characterized by a lenticular shape (in red in Fig. 13a), located between $X=100 \mathrm{~m}$ and $\mathrm{X}=145 \mathrm{~m}$ to a depth of $6 \mathrm{~m}$, and between $\mathrm{X}=150 \mathrm{~m}$ and $\mathrm{X}=220 \mathrm{~m}$ at a depth of $5 \mathrm{~m}$. A more homogeneous electro-layer was placed at a depth greater than $19 \mathrm{~m}$ with relatively conductive values $(<15 \Omega * \mathrm{~m})$, compatible with the presence of water.

In ERT2 tomography (see Fig. 13b), a superficial electrolayer can be observed up to approximately $4-5 \mathrm{~m}$ with relatively resistive values $(>70 \Omega * \mathrm{~m}$ ) located between $\mathrm{X}=0 \mathrm{~m}$ and $X=180 \mathrm{~m}$. A deeper electro-layer is visible at a depth of $12 \mathrm{~m}$ with relatively conductive values $(<15 \Omega * \mathrm{~m})$. The most relevant finding is a relatively conductive lenticular $(<10 \Omega * \mathrm{~m})$ suggesting the presence of an aquifer.

In ERT3 tomography there are two electro-layers: one is superficial (up to about $6 \mathrm{~m}$ ), abscissa 0 and $8 \mathrm{~m}$, relatively resistive $(>50 \Omega * \mathrm{~m})$ and a deeper one relatively conductive $(<10 \Omega * \mathrm{~m})$. Between $\mathrm{X}=90 \mathrm{~m}$ and the end of the tomography there is a relatively resistive body $(>70 \Omega * \mathrm{~m})$ at a depth approximately around $35 \mathrm{~m}$.

Except for a part of ERT3 tomography characterized by relevant resistivity (as expected in a desert area) the rest of the same ERT3 and the two ERT1 and ERT2 tomographies, crossing an area covered by vegetation, exhibit values related to relatively conductive bodies. These are particular evident from the surface up to 30-40 m depth, suggesting the potential presence of water with a high salt content.
The magnetic surveys, conducted in the pond at south of the Acllawasi palace (see M1 in Fig. 13c, right), allowed the identification of two linear magnetic anomalies likely due to the presence of canals that feed the cistern. The hypothesis has been confirmed by georadar. In fact, radargram GPR1, in correspondence with the magnetic anomalies, revealed local reflectors at a depth of $60-80 \mathrm{~cm}$ compatible with the presence of canals (see radargram GPR1 in Fig. 13d). Another magnetic map (M2 in Fig. 13c, left) revealed other anomalies related to the presence of potential canals.

Finally, to the south west of the M2 map, the integration of georadar and magnetic techniques allowed the detection of anomalies related to the presence of an aqueduct that carried the water to the Urpiwachaq lagoon (Fig. 14). This was confirmed by trial excavations (see trial 1 and 2 in Fig. 14).

\section{Conclusion}

In this study the archaeological record and new results from geophysical prospections have been integrated (see flowchart in Fig. 12) to improve the knowledge of the canal system in the area comprised between the Acllawasi palace and the lagoon (see Fig. 11).

The archaeogeophysical investigations we conducted allowed us to characterize the subsoil at different depths to improve the knowledge of the aquifers and the presence of buried canals, some of them in relation with canal sectors unearthed by archaeologists before geophysical prospecting (in particular see Fig. 14).

In particular, ERT allowed to identify the aquifer which fed the system of ponds and canals of Acllawasi at a depth of around $12 \mathrm{~m}$.

Magnetic investigations enabled to characterize the water supply system of ponds, imaging a number of canals whose depth has been estimated by GPR.

Finally, GPR revealed the presence of a drainage canal which connected the main pond with the lagoon.

On the basis of the trial excavations, the archaeogeophysical integrated approach herein adopted enabled us to: (1) fully characterize the canal system; (2) optimize time and costs compared to an excavation campaign; (3) avoid further destructive activities.

In the next future, further research will be conducted, using the techniques mentioned here and other remote sensing methods [26], with the aim to further improve the knowledge of the entire complex system of canals 
and to verify if the water is the product only of the underground filtrations or if it would derive from the Lurin River.

\section{Authors' contributions}

The archaeological research was carried out by DP-E and JO. The maps, photographs, and some textual citations correspond to the results of the research and conservation program of the archaeological sanctuary of Pachacamac, financed by Qhapaq Nan proyect of the Ministry of Culture of Peru. With respect to archaeogeophysical investigations: NM and RL conceived and directed archaeo-geophysical campaign, wrote "Archaeogeophysical approach used for the study of the Urpiwachaq lagoon" and "Results and discussion" sections. The geophysical data acquisition has been made by Luigi Capozzoli, Felice Perciante, Gerardo Romano, and Maria Sileo with the contribution of Enzo Rizzo to the processing of geophysical data. The interpretation was made by Enzo Rizzo, Gerardo Romano, RL and NM. Gerardo Romano contributed to "Archaeogeophysical approach used for the study of the Urpiwachaq lagoon" section.

\section{Author details}

${ }^{1}$ Pachacamac Museum-Ministry of Culture of Peru, Lima, Peru. ${ }^{2}$ University of Bari, Bari, Italy. ${ }^{3}$ CNR-Istituto di Metodologie di Analisi Ambientale, Potenza, Italy. ${ }^{4}$ CNR-Istituto per i Beni Archeologici e Monumentali, Potenza, Italy.

\section{Competing interests}

The authors declare that they have no competing interests.

\section{Availability of data and materials}

All the data supporting the conclusions are included within the article.

\section{Funding}

Not applicable.

\section{Publisher's Note}

Springer Nature remains neutral with regard to jurisdictional claims in published maps and institutional affiliations.

Received: 22 March 2018 Accepted: 12 November 2018

Published online: 29 November 2018

\section{References}

1. Canziani J, Canziani E, Tubino P. Urpiwachaq: Proyecto de recuperación paisajista en el santuario arqueológico de Pachacamac. Libro: Urpiwachaq: gestión y puesta en valor de la laguna. Lima: Ministerio de Cultura del Perú y Universidad del Pacífico; 2015.

2. Ávila F. Dioses y hombres de Huarochirí. Narración quechua recogida por Francisco de Ávila (Segunda edición ed.). (J. M. Arguedas, Trad.). Lima: Universidad Antonio Ruiz de Montoya. 2007.

3. Kaulicke P. La sombra de Pachacamac: Huari en la costa central. Núm: Boletín de arqueología PUCP; 2000. p. 4.

4. Vanstan I. Textiles from Beneath. The temple of Pachacamac, Peru. A part of the Uhle collection of the. Philadelphia: University Museum. University of Pennsylvania; 1967.

5. Jacay J, Oshiro J. Estudio geológico de la laguna Urpiwachaq. Libro: Urpiwachaq: gestión y puesta en valor de la laguna. Lima: Ministerio de Cultura del Perú y Universidad del Pacífico; 2015.

6. Shimada I, Rostworowski M, Segura R. Informe de la primera temporada de campo del proyecto arqueológico Pachacamac. Sitio arqueológico. de Pachacamac, valle bajo de Lurín, costa central. Lima: del Perú; 2003.
7. Rostworowski M. Recursos naturales renovables y pesca, siglos XVI y XVII; Curacas y sucesiones. Costa Norte. En Obras Completas IV. Lima: Instituto de Estudios Peruanos; 2005.

8. Rostworowski M. Estructuras andinas del poder. Ideología religiosa y política. Lima: Instituto de Estudios Peruanos; 1983.

9. Taylor G. Ritos y tradiciones de Huarochirí. Manuscrito quechua de comienzos de siglo XVII. Lima: Instituto de Estudios Peruanos, Instituto Francés de Estudios Andinos; 1987.

10. Uhle M. Pachacamac, report of the William Pepper. Philadelphia: Department of Archaeology, University of Pennsylvania; 1903. p. 104.

11. Tello JC. Arqueología de Pachacamac: excavaciones en Urpi Kocha y Urpiwachaq. Lima: Cuadernos de Investigación del Archivo Tello, 5 (Museo Nacional de Arqueología, Antropología e Historia del Perú; Universidad Nacional Mayor de San Marcos); 2008.

12. Bueno A. Potrero Urpiwachaq. Informe del Proyecto de Investigación. "Arqueología en el terreno colindante a Pachacamac propiedad de la Universidad del Pacífico". Manuscrito no publicado. Instituto Nacional de Cultura. 1999

13. Rosas Rintel M. Proyecto de puesta en valor de la laguna Urpiwachaq. Anteproyecto de excavaciones arqueológicas: Manuscrito no publicado; 2010.

14. Ramos Giraldo J. Santuario de Pachacamac. Cien años de arqueología en la Costa Central. Lima: Municipalidad del Distrito de Lurín Editorial Cultura Andina; 2011.

15. Zambrano R. Informe Final del Proyecto de Investigación arqueológica en el Bosque de las Casuarinas. Jesús María: Manuscrito no publicado. Ministerio de Cultura, Universidad del Pacífico; 2013.

16. Oshiro J. Investigación arqueológica en la laguna Urpiwachaq. En: Urpiwachaq: gestión y puesta en valor de la laguna, Pozzi-Escot y Oshiro editores. Lima. Ministerio de Cultura del Perú y Universidad del Pacífico. 2015.

17. Fernández A. Informe final proyecto arqueológico Urpay Huachac. Jesús María: Manuscrito no publicado. Universidad del Pacífico; 2006.

18. Espinoza Soriano W. El Templo Solar de Paramonga y los Acuarios de Pachacámac. Jesús María: Bulletin de I'Institut Français d'Etudes Andines; 1974. p. 3.

19. Pozzi-Escot D. Informe Final-PIA Calle Norte-Sur y Segunda Muralla del Santuario de Pachacamac. Primera edición: Ministerio de Cultura del Perú; 2010.

20. Pozzi-Escot D, Bernuy K. Pachacamac: calle Norte-Sur. Primera edición: Investigaciones arqueológicas. Lima. Ministerio de Cultura del Perú; 2010.

21. Lasaponara R, Masini N, Pecci A, Perciante F, Pozzi-Escot D, Rizzo E, Scavone M, Sileo M. Qualitative evaluation of COSMO SkyMed in the detection of earthen archaeological remains: the case of Pachamacac (Peru)". Journal of Cultural heritage, en prensa.

22. Masini N, Capozzoli L, Romano G, Sieczkowska D, Sileo M, Bastante J, Victoria FA, Ziolkowski M, Lasaponara R. Archaeogeophysical based approach for Inca archaeology: overview and one operational application. Surv Geophys. 2018;39:1239-62. https://doi.org/10.1007/s10712-018-9502-2.

23. Masini N, Capozzoli L, Chen P, Chen F, Romano G, Lu P, Tang P, Sileo M, Ge Q, Lasaponara R. Towards an operational use of geophysics for archaeology in Henan (China): archaeogeophysical investigations, approach and results in Kaifeng. Remote Sens. 2017;9(8):809. https://doi.org/10.3390/rs9080809.

24. Fedi M, Cella F, Florio G, Manna M, Paoletti V. Geomagnetometry for archaeology. In: Masini N, Soldovieri F, editors. Sensing the past. From artifact to historical site. Series: geotechnologies and the environment, vol. 16. Berlin: Springer; 2017. p. 203-30.

25. Loke MH, Barker RD. Practical techniques for $3 \mathrm{D}$ resistivity surveys and data inversion. Geophys Prospect. 1996;44(3):499-523.

26. Lasaponara R, Masini N, editors. Image enhancement, feature extraction and geospatial analysis in an archaeological perspective. In: Satellite remote sensing: a new tool for archaeology. Berlin: Springer; 2012. p. 17-64. https://doi.org/10.1007/978-90-481-8801-7_2. ISBN 978-90-481-8800-0. 